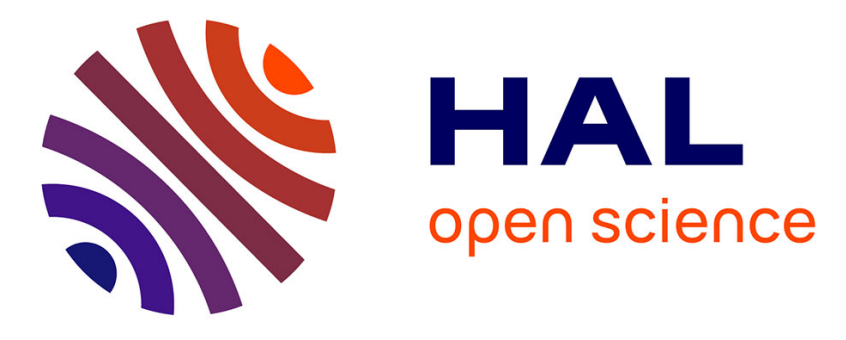

\title{
Stable isotope patterns in micronekton from the Mozambique Channel
}

Frédéric Ménard, Hermann Doris Benivary, Nathalie Bodin, Nathalie

Coffineau, François Leloc'H, Thomas Mison, Pierre Richard, Michel Potier

\section{- To cite this version:}

Frédéric Ménard, Hermann Doris Benivary, Nathalie Bodin, Nathalie Coffineau, François Leloc'H, et al.. Stable isotope patterns in micronekton from the Mozambique Channel. Deep Sea Research Part II: Topical Studies in Oceanography, 2014, 100, pp.153 - 163. 10.1016/j.dsr2.2013.10.023 hal-01081597

\section{HAL Id: hal-01081597 https://hal.science/hal-01081597}

Submitted on 10 Nov 2014

HAL is a multi-disciplinary open access archive for the deposit and dissemination of scientific research documents, whether they are published or not. The documents may come from teaching and research institutions in France or abroad, or from public or private research centers.
L'archive ouverte pluridisciplinaire HAL, est destinée au dépôt et à la diffusion de documents scientifiques de niveau recherche, publiés ou non, émanant des établissements d'enseignement et de recherche français ou étrangers, des laboratoires publics ou privés. 
1 Stable isotope patterns in micronekton from the Mozambique Channel

2 Frédéric Ménard ${ }^{\mathrm{a}}{ }^{*}$, Herman Doris Benivary ${ }^{\mathrm{b}}$, Nathalie Bodin ${ }^{\mathrm{a}}$, Nathalie Coffineau ${ }^{\mathrm{a}}$, François

3 Le Loc' $^{\mathrm{a}}$, Thomas Mison ${ }^{\mathrm{a}}$, Pierre Richard ${ }^{\mathrm{c}}$, Michel Potier $^{\mathrm{a}}$

4 a Institut de Recherche pour le Développement (IRD), UMR 212 EME (IRD/IFREMER/UM2),

5 Avenue Jean Monnet, BP 171, 34203 Sète cedex, France

$6{ }^{b}$ Institut Universitaire de Science de l'Environnement et de Santé, Université d'Antsiranana,

7 Antsiranana 20, BP 0, Madagascar

8 ' $U M R 7266$ CNRS-Université de La Rochelle, 2 rue Olympe de Gouges, 17000 La Rochelle,

9 France

$10 *$ Corresponding author

11 frederic.menard@ird.fr

12 Tel +33(0)4 99573230

$13 \quad \mathrm{Fax}+33(0) 499573295$ 


\section{ABSTRACT}

We measured the stable carbon $\left(\delta^{13} \mathrm{C}\right)$ and nitrogen $\left(\delta^{15} \mathrm{~N}\right)$ isotopic composition of tissues of micronektonic organisms (fishes, squids, crustaceans and gelatinous organisms) collected in the Mozambique Channel during two scientific cruises in 2008 and 2009. The oceanic circulation in the Mozambique Channel is dominated by mesoscale cyclonic and anticyclonic eddies which play a key role in biological processes of less-productive deep-sea ecosystems. We investigated the potential impact of mesoscale features on the $\delta^{13} \mathrm{C}$ and $\delta^{15} \mathrm{~N}$ values of 32 taxa of micronekton. Fishes, squids, crustaceans and gelatinous organisms encompassed a wide range of isotopic niches, with large overlaps among species. Our results showed that mesoscale features did not really influence the isotopic signatures of the sampled organisms, although cyclonic eddies can occasionally impact the nitrogen signatures of micronekton. We show that $\delta^{13} \mathrm{C}$ values were intermediate between standard offshore and nearshore signatures, suggesting that pelagic production in the Mozambique Channel could be partly supported by the transport and export of inorganic and organic particles from the Mozambican coast toward the offshore area. Trophic levels calculated from $\delta^{15} \mathrm{~N}$ values ranged from 2.6 to 4.2 , showing that micronekton taxa can be tertiary consumers in the Mozambique Channel. Our findings evidenced clusters of micronektonic organisms according to their $\delta^{15} \mathrm{~N}$ or $\delta^{13} \mathrm{C}$ isotopic signatures, but variations in stable isotope values reflect a complex set of embedded processes linked to physical mesoscale dynamics (rotational dynamics of eddies) and basic biology and ecology of micronektonic organisms (vertical habitat, migration pattern, dietary habits, body length) that are discussed with regard to the stable isotope method based on time-integrated assimilated food. 
KEYWORDS: Micronekton, $\delta^{13} \mathrm{C}, \delta^{15} \mathrm{~N}$, Mesoscale, Oceanic eddies, Diel vertical migration, Trophic level, Mozambique Channel.

\section{INTRODUCTION}

The circulation in the Mozambique Channel (south-west Indian Ocean) is ruled by an important mesoscale activity (de Ruijter et al., 2002). Mesoscale rotating eddies propagate southwards along the western edge of the channel (Quartly and Srokosz, 2004; Schouten et al., 2003). These mesoscale features contribute to ocean mixing processes and consequently impact the biological activity at different scales. Cyclonic eddies (clockwise rotating in the southern hemisphere) generate vertical pumping of nutrients in their centres (Bakun, 2006; Chelton et al., 2011; McGillicuddy Jr et al., 1998), enhancing local primary production (Benitez-Nelson et al., 2007; Mizobata et al., 2002; Tew-Kai and Marsac, 2009). On the opposite, anticyclonic eddies (counter-clockwise rotating) are usually associated with low chlorophyll levels (Bakun, 2006; Chelton et al., 2011). However, phytoplankton enrichment has also been associated with the upward movement of nutrient rich waters at the edges of either cyclonic or anticyclonic eddies (Mizobata et al., 2002; Quartly and Srokosz, 2004). In addition, coastal primary production produced on the western side of the channel can be horizontally advected by continuous contra-rotating eddy pairs, referred to as dipoles and propagating southwards (Roberts et al., this issue; Ternon et al., this issue). By influencing the horizontal and vertical distribution at the base of the food web (nutrients, phytoplankton and zooplankton), these features have been suggested to alter the distribution of intermediate trophic links such as micronekton, and thus the distribution of upper-trophic level organisms. 
Biological responses to mesoscale eddies have been documented for mesozooplankton and fish larvae (Bakun, 2006; Muhling et al., 2007), for tunas and swordfish (Young et al., 2001);(Seki et al., 2002), for turtles (Lambardi et al., 2008; Polovina et al., 2004), for seabirds (Hyrenbach et al., 2006; Nel et al., 2001; Weimerskirch et al., 2004), or for marine mammals (Bailleul et al., 2010). In spite of their importance, the impact of mesoscale features on micronektonic organisms remains fragmented and is still poorly quantified (see Potier et al., this issue). Recent investigations showed that eddies can shape the distribution and the aggregation patterns of micronekton through bottom-up processes (Drazen et al., 2011; Sabarros et al., 2009). Micronekton refers to small, but actively swimming, organisms (ca. 1 to $20 \mathrm{~cm}$ ), mainly crustaceans, fishes, and squids, that form the link between zooplankton and large fish predators in open-sea ecosystems (Brodeur and Yamamura, 2005; Potier et al., 2007). Most of micronekton performs large diel vertical migrations during the crepuscular periods (dawn and dusk), from depths below 400 m during the day to the surface layers at night (Benoit-Bird et al., 2009).

In this work, we analyzed the ratios of stable carbon $\left(\delta^{13} \mathrm{C}\right)$ and nitrogen $\left(\delta^{15} \mathrm{~N}\right)$ isotopes in the tissues of micronektonic organisms collected in the Mozambique Channel within the framework of the MESOBIO programme (Ternon et al., this issue). Carbon and nitrogen isotopes have often successfully been applied to investigate foraging ecology and trophic relationships in marine ecosystems (Cherel et al., 2010; Fanelli et al., 2011; Ménard et al., 2007; Olson et al., 2010; Revill et al., 2009; Stowasser et al., 2012). Stable isotope ratios of carbon and nitrogen in consumer tissues reflect those of their prey in a predictable manner, and depend on the isotopic signature at the base of the food web (Fry, 2006; Post, 2002). The $\delta^{15} \mathrm{~N}$ values mainly estimates the relative trophic position of an animal thanks to predictable enrichment of ${ }^{15} \mathrm{~N}$ with increasing trophic level (Vanderklift and Ponsard, 2003). 
85 Thus, $\delta^{15} \mathrm{~N}$ has been used for quantifying and comparing trophic levels of consumers (Cherel

et al., 2008). By contrast, $\delta^{13} \mathrm{C}$ variations are used to determine the sources of primary production, inshore versus offshore or pelagic versus benthic contribution to food intake (Rubenstein and Hobson, 2004). Different processes affect isotopic baselines of $\delta^{13} \mathrm{C}$ and $\delta^{15} \mathrm{~N}$, including nutrient source, primary productivity, depth and ocean mixing processes (Fry, 2006). The present work aims (1) to investigate the potential impact of mesoscale features on the ratios of stable carbon and nitrogen isotopes of micronektonic organisms, and (2) to interpret the isotopic niches and the trophic levels of micronektonic species in the Mozambique Channel.

\section{MATERIAL AND METHODS}

\subsection{Sample collection}

Micronekton samples were collected from two scientific cruises during December 2008 on board R/V Fridtjof Nansen (2008 ASCLME survey $n^{\circ}$ 4, called hereafter MC08A) and during November 2009 on board R/V ANTEA (referred to as MC09B). A Young Gadoid Pelagic Trawl (YGPT) was used during MC09B with a cod-end lined with $5 \mathrm{~mm}$ knotless nylon delta mesh netting, while an Akrahamn pelagic trawl with cod-end $10 \mathrm{~mm}$ was used during MC08A. Trawls were conducted during the day on aggregations detected by acoustics, and during the night at the surface on sound scattering layers $(0-200 \mathrm{~m})$. Night trawl depth was selected according to highest acoustic detections. Each trawl was towed for $30 \mathrm{~min}$ at a speed of 3 to 4 knots. A total of 16 and 18 trawls were performed during MC08A and MC09B, respectively (from which $2 / 3$ were carried out at nighttime). The whole catch was sorted and soft tissues of selected micronekton species were removed for further isotopic analyses: dorsal muscle for fishes, mantle for squids, abdomen for crustaceans and body wall for pelagic gastropods 
molluscs, siphonophorans, leptocephali larvae and salps. Body length of each individual was measured except for salps: standard length (SL) for fishes, dorsal mantle length (DML) for squids, cephalothorax length (CT) for crustaceans, and total length for the other taxa.

\subsection{Stable isotope analysis}

Samples were freeze-dried and ground to a fine homogeneous powder. Since lipids are depleted in ${ }^{13} \mathrm{C}$, lipids were removed using dichloromethane on an accelerated solvent extraction system (ASE ${ }^{\circledR}$, Dionex;(Bodin et al., 2009). This method does not alter $\delta^{15} \mathrm{~N}$ signatures. The extent of lipid extraction was checked through the $\mathrm{C} / \mathrm{N}$ mass ratio of the samples (Post et al., 2007). Lipid-free samples were dried at $50^{\circ} \mathrm{C}$ before processing, and then 300 to $400 \mu \mathrm{g}$ of homogenized powder were packed into $8 \times 5 \mathrm{~mm}$ tin containers. Isotopic ratios were determined by a continuous flow mass spectrometer coupled on line to an elemental analyzer. Replicate measurements of internal laboratory standards indicated measurement errors less than $0.15 \%$ and $0.20 \%$ for $\delta^{13} \mathrm{C}$ and $\delta^{15} \mathrm{~N}$, respectively. Triplicate measurements performed on some samples confirmed that analytical reproducibility was very good (0.2\% maximum variation). Isotopic ratios are expressed in the conventional $\delta$ notation as parts per thousand (\%o) deviations from the international standards: atmospheric nitrogen $\left(\mathrm{N}_{2}\right)$ for $\delta^{15} \mathrm{~N}$ and VPDB Belemnite for $\delta^{13} \mathrm{C}$.

$$
\delta X=\left(R_{\text {sample }} / R_{\text {standard }}-1\right) \times 1000
$$

where $\mathrm{X}$ is ${ }^{15} \mathrm{~N}$ or ${ }^{13} \mathrm{C}, \mathrm{R}$ is the corresponding ratio ${ }^{15} \mathrm{~N} /{ }^{14} \mathrm{~N}$ or ${ }^{13} \mathrm{C} /{ }^{12} \mathrm{C}$.

\subsection{Data analysis}

Satellite altimetry allows identification of mesoscale features (Chelton et al., 2007). One mesoscale feature among five classes (anticyclone, A; cyclone, C; divergence, D; front, F; and 
shelf station, S) was assigned to each of the 34 trawling stations. The classification of each individual station was processed using three explanatory variables (sea level anomaly, geostrophic speed and bathymetry) and a discriminant function estimated from an extra training dataset (Lamont et al., this issue). Ocean bathymetry was extracted from ETOPO1 Global Topography (data access: http://www.ngdc.noaa.gov/mgg/global/global.html). Sea level anomaly and the corresponding geostrophic speed were extracted from AVISO products "DT-MSLA Ref" (Delayed Time, DT; Reference, "Ref") with $0.33 \times 0.33^{\circ}$ spatial resolution on a Mercator grid. The predictions from the linear discriminant analysis were estimated for each station using the values taken by the three explanatory variables at the corresponding temporal and spatial positions.

Links between isotope values $\left(\delta^{15} \mathrm{~N}\right.$ and/or $\left.\delta^{13} \mathrm{C}\right)$, and broad categories and mesoscale features were investigated using multivariate analysis of variance (MANOVA), Kruskal-Wallis (KW) non-parametric tests and univariate regression tree (URT). URT is a powerful statistical tool that explains the variation of a single response variable $\left(\delta^{15} \mathrm{~N}\right.$ or $\left.\delta^{13} \mathrm{C}\right)$ using several explanatory variables by growing a tree that partitions the data set into mutually exclusive groups (Venables and Ripley, 2002). The objective is to partition the response into homogeneous groups. All the data are represented by a single node at the top of the tree. Then the tree is built by repeatedly splitting the data. Each split is defined by a simple rule based on a single explanatory variable. Splits are chosen to maximize the homogeneity of the resulting two nodes. However, the splitting procedure grows an overlarge tree. To keep the tree reasonably small, a prune back procedure is applied. Each final group is characterized by mean values of $\delta^{15} \mathrm{~N}$ or $\delta^{13} \mathrm{C}$. 
155 As the content of ${ }^{15} \mathrm{~N}$ in animal tissues is biomagnified along the length of a food chain (Post, 156 2002), trophic levels (TL) of micronekton taxa were calculated on the basis of isotopic 157 measurements using the following equation:

$$
T L=2.0+\frac{\delta^{15} \mathrm{~N}_{i}-\delta^{15} \mathrm{~N}_{\text {primary }} \text { consumer }}{3.2}
$$

where $\delta^{15} N_{i}$ is the nitrogen isotopic composition of any given micronekton taxon $i, \delta^{15} N_{\text {primary }}$ consumer is the $\delta^{15} \mathrm{~N}$ reference baseline value at trophic level 2, and 3.2\%o is an estimate of the average increase of $\Delta^{15} \mathrm{~N}$ per trophic level (Cherel et al., 2010; Sweeting et al., 2007). Using primary consumers as a baseline might reduce error in the estimation of $T L$ (Martínez del Rio et al., 2009). Salps are known to be filter-feeders grazing on phytoplankton and other small food items. They were often chosen as the primary consumer species for estimating trophic levels using equation (2) (Cherel et al., 2010, 2008; Stowasser et al., 2012). Therefore, we chose average $\delta^{15} \mathrm{~N}$ value of Salpa maxima as the reference value for the food base. The mean was computed using three $\delta^{15} \mathrm{~N}$ values $(5.0,5.2,5.2 \%$ ) from MC08A and one (5.2\%o) from MC09B.

\section{RESULTS}

Fig. 1 displays the location of the 34 trawls categorized in four mesoscale feature classes

172 (cyclones $C$, anticyclones $A$, fronts $F$, divergences $D$ and shelf station S). A total of 545 organisms amongst 32 taxa were analyzed (Table 1). Not all micronekton taxa were caught at all mesoscale features, in particular few individuals were collected in anticyclones and cyclones (68 and 77, respectively) compared with those collected in divergences and fronts (187 and 121, respectively). 
Taxa were divided in four broad categories: gelatinous organisms (Salpa maxima, siphonophorans, the pelagic gastropod molluscs Carinaria lamarckii and leptocephali larvae), crustaceans (Funchalia spp., Oplophorus sp. and O. typus), squids (Cranchia scabra, Ornithoteuthis volatilis, Sthenoteuthis oualaniensis), and fishes. Fishes represented 16 species, 5 genera and 1 family. The family Bramidae grouped juveniles of Pterycombus petersii and of other undetermined species: they were not segregated by both $\delta^{15} \mathrm{~N}$ (Kruskall-Wallis, $H=1.19, P>0.27)$ and $\delta^{13} \mathrm{C}$ values $(H=0.43, P>0.50)$. The Thunnus spp. category comprised very small juvenile scombrids that were not identified. Psenes spp. comprised 2 species (P. cyanophrys, P. whiteleggii) that were not segregated by their $\delta^{15} \mathrm{~N}$ signatures (Kruskall-Wallis, $H=1.78, P>0.18$ ), but slightly segregated by $\delta^{13} \mathrm{C}$ (KruskallWallis, $H=4.0, P=0.045)$. The genus Diaphus is taxonomically one of the most difficult in the family Myctophidae. We accurately identified three species (D. garmani, D. metopoclampus, D. richardsoni). The Diaphus spp. category groups other species that were not identified. Juveniles were collected for Bramidae, Decapterus sp., Pterycombus petersii, Psenes spp. and Thunnus spp only.

Means of $\mathrm{C} / \mathrm{N}$ mass ratio encompassed a narrow range (between 3.0 and 3.4 for 30 taxa; only Salpa maxima and leptocephali larvae had ratios greater than 4; Table 1). Such small values indicated low lipid content after lipid removal, thus allowing accurate comparisons of $\delta^{13} \mathrm{C}$ values among sample types. Isotopic analyses revealed a considerable range of $\delta^{13} \mathrm{C}$ and $\delta^{15} \mathrm{~N}$ mean values, 3.3 and $6.9 \%$, respectively. The $\delta^{13} \mathrm{C}$ mean values ranged from $-20.6 \pm$ $0.57 \%$ (letocephal larvae) to $-17.3 \pm 0.24 \%$ (Oplophorus sp.) (Table 1 ). The $\delta^{15} \mathrm{~N}$ ranged from $5.2 \pm 0.11 \%$ (Salpa maxima) to $12.1 \pm 0.44 \%$ (Diaphus metopoclampus).

The four broad categories (fishes, squids, crustaceans and gelatinous organisms) were segregated by their isotope signatures of both nitrogen and carbon treated as a multivariate 
response (MANOVA, Wilk's lambda, $F_{3,540}=58.37, P<0.0001$ ). They were also segregated in

204

205

206

207

208

209

210

211

212

213

214

215

216

217

218

219

220

221

222

223

224

225

226

their isotopic signatures in both $\delta^{13} \mathrm{C}$ (univariate analysis, $\mathrm{KW}$ test, $H=115.0, P<0.0001$; pairwise comparisons indicated that crustaceans and squids were not significantly different) and $\delta^{15} \mathrm{~N}$ values (KW test, $H=56.0, P<0.0001$; fishes and squids did not differ significantly). Fig. 2 displays a summary of $\delta^{13} \mathrm{C}$ and $\delta^{15} \mathrm{~N}$ values (mean \pm standard deviation) of all the taxa grouped by broad categories. To give a better picture of the trophic structure of the assemblages, taxa of the four broad categories were placed in sequence according to their nitrogen and carbon mean values (Fig. $3 a$ and $3 b$, respectively). Tests were then conducted by categories:

- The 22 taxa of fish were segregated by their overall isotopic signatures (MANOVA, Wilk's lambda, $\left.F_{21,354}=14.99, P<0.0001\right)$, and both $\delta^{13} \mathrm{C}(\mathrm{KW}$ test, $H=151.1, P<0.0001)$ and $\delta^{15} \mathrm{~N}$ values ( $\mathrm{KW}$ test, $H=249.6, P<0.0001$ ). The most enriched values were found for known deep migrating mesopelagic fishes such as several Myctophidae (all of the genus Diaphus, Lobianchia gemellarii), the bregmacerotid Bregmaceros macclellandii, the notosudid Scopelosaurus hoedti, and the sternoptychid Argyropelecus aculeatus. Cubiceps pauciradiatus (Nomeidae) and Decapterus sp. (Carangidae) exhibited large standard deviations of $\delta^{15} \mathrm{~N}$ thanks to a subset of specimens caught in one cyclone of MCO9B with very high $\delta^{15} \mathrm{~N}$ values (see below).

- Overall isotopic signatures differed between the three squid species (MANOVA, Wilk's lambda, $\left.F_{2,101}=4.90, P<0.001\right)$, but only the $\mathrm{KW}$ test based on $\delta^{13} \mathrm{C}$ signatures was significant $\left(H=10.62, P<0.005\right.$ for $\delta^{13} \mathrm{C} ; H=0.85, P=0.66$ for $\left.\delta^{15} \mathrm{~N}\right)$.

- For crustaceans (three taxa) and gelatinous organisms (four taxa), multi- and univariate tests were all significant. Standard deviations of both $\delta^{13} \mathrm{C}$ and $\delta^{15} \mathrm{~N}$ for leptocephali larvae were very high, while the nitrogen signatures of Salpa maxima varied very little $(5.2 \pm$ 
$0.11 \%$ ). Oplophorus typus (crustacean) was the only non-fish taxa having a $\delta^{15} \mathrm{~N}$ average greater than $10.0 \%$ o (Fig. 3a), and Oplophorus sp. had the most ${ }^{13} \mathrm{C}$ enrichment.

\subsection{Impact of mesoscale features}

231 No clear pattern emerged from $\delta^{13} \mathrm{C}$ vs. $\delta^{15} \mathrm{~N}$ bi-plots of the 545 individuals categorized by broad category and by mesoscale feature (figures not shown). To investigate the structure of the data and assess the influence of eddies, we conducted univariate regression tree analyses (URT) on $\delta^{15} \mathrm{~N}$ and $\delta^{13} \mathrm{C}$ values using cruise, broad category, mesoscale feature, taxon and body length as covariates. Five groups were identified by the URT based on $\delta^{15} \mathrm{~N}$ values (Fig. 4a). Groups were sorted in order of increasing $\delta^{15} \mathrm{~N}$ predicted values (Fig. 4b). The first splits of the pruned tree separated taxa: one group of low $\delta^{15} \mathrm{~N}$ values clustered gelatinous organisms (except siphonophorans), small fishes and one crustacean (Funchalia spp.); the other group put together deep migrating mesopelagic organisms (11 fish taxa and the crustacean Oplophorus typus) with rather high $\delta^{15} \mathrm{~N}$ values. A further split separated cyclonic eddies from the four other classes (anticyclones, divergences, fronts and shelf stations). The non cyclonic group mixed taxa from the four broad categories. The "cyclonic" 243 branch of the pruned tree separated two groups (Fig. 4a and 4b): Cyclonic 1 grouped 22 individuals (14 fishes, three specimens of the crustacean Oplophorus sp. and five specimens 245 of the squid Cranchia scabra) with intermediate $\delta^{15} \mathrm{~N}$ values (predicted value of 9.4\%o); Cyclonic 2 clustered six specimens of Cubiceps pauciradiatus (fish) and one Ornithoteuthis 247 volatilis (squid) collected in the same cyclone sampled in November 2009 (cruise MC09B), with the highest $\delta^{15} \mathrm{~N}$ values (predicted value of $14.1 \%$ ).

249 Four groups were identified by the URT based on $\delta^{13} \mathrm{C}$ values. Taxon was the only significant covariate used to develop the pruned tree (Fig. 5a and 5b). Group 2 clustered most of the 
micronekton taxa (Fig. 5a and 5b) with a predicted average of $-18.7 \%$. Group 3 classified

252

253

254

255

256

257

258

259

260

261

262

263

264

265

266

267

268

269

270

271

272

273

taxa with the highest ${ }^{13} \mathrm{C}$ enrichment (predicted $\delta^{13} \mathrm{C}$ value of $-18.2 \%$ ). Leptocephali larvae were segregated owing to their low $\delta^{13} \mathrm{C}$ values.

\subsection{Trophic levels and size}

Since size is an important factor structuring trophic links, we looked at the potential relationships between body length and $\delta^{15} \mathrm{~N}$ values. However we were limited by sample sizes and body length ranges, and size effect was tested for ten taxa only (Table 1). The fishes Bramidae, Cubiceps pauciradiatus, Thunnus spp. and the squid Sthenoteuthis oualaniensis showed a significant body length effect (Fig. 6 and Table 2). One outlier for S. oualaniensis was removed from the linear regression (Fig. 6b). Fig. $6 c$ reveals that a simple model was not appropriate for $C$. pauciradiatus: the six individuals sampled in the cyclone of November 2009 were cut off from the other individuals. The final model did not select two separate linear regressions. The most parsimonious model retained parallel regressions (same estimated slope) and different intercepts (Table 2).

Estimated TLs within the micronekton consumers of Mozambique Channel ranged from 2.2 (leptocephali larvae) to 4.2 (the fish D. metopoclampus), encompassing theoretically two trophic levels (Table 1). Of course, estimated TLs exhibited the same patterns as $\delta^{15} \mathrm{~N}$ values because the only unknown in equation (2) was the nitrogen isotopic composition of micronekton taxa. The three squid species shared the same TL (3.3 to 3.4), and the deep migrating mesopelagic fishes and the crustacean 0 . typus had the highest TLs.

\section{DISCUSSION}


To our knowledge this study is the first that investigates the potential impact of mesoscale eddies on the isotopic signatures of a large assemblage of micronekton from gelatinous organisms to fish. An extensive investigation conducted on two counter-rotating eddies off Western Australia analyzed mainly the impact of eddies on the isotopic composition of dissolved inorganic nitrogen, particulate organic matter and mesozooplankton (Waite et al., 2007). Fish larvae identified at the family level were also collected with small nets, allowing the analysis of eel leptocephals and of small-sized specimens of Myctophidae, Sternoptychidae, Paralepididae, Phosichthyidae and Scorpaenidae only. The results of Waite et al. (2007) showed no significant difference in the $\delta^{15} \mathrm{~N}$ signature between the fish larvae from the two eddies, but myctophid larvae from the warm-core eddy (i.e., counter-clockwise rotational sense) are significantly enriched in ${ }^{13} \mathrm{C}$ relative to those from the cold-core eddy (i.e., cyclonic rotation). In our study, the fish taxa sampled covered several main open-ocean micronekton fish families (juveniles and/or adults) found in the Mozambique Channel: Myctophidae, Nomeidae, Bramidae, Phosichthyidae, Sternoptychidae, Notosudidae, Gonostomatidae, Paralepididae, Bregmacerotidae and Carangidae. Our findings showed that mesoscale features did not have any clear impact on the carbon and nitrogen signatures of micronekton in the Mozambique Channel. The 32 taxa of crustaceans, squids and fishes encompassed a wide range of isotopic niches, with large overlaps among species. Regression trees evidenced patterns with clusters of organisms according to their $\delta^{15} \mathrm{~N}$ or $\delta^{13} \mathrm{C}$ isotopic signatures. We attempt henceforward to examine some hypotheses supported by our results, taking into account the nature of our data and the stable isotope method.

\subsection{Isotopic patterns amongst mesoscale features}


Eddies play a key role in biological processes of less-productive deep-sea ecosystems by

298

299

300

301

302

303

304

305

306

307

308

309

310

311

312

313 converting physical energy into trophic energy (Bakun, 2006; Godø et al., 2012). They have been suggested to impact the distribution of marine organisms through bottom-up effects (Domokos, 2009; Domokos et al., 2007; Drazen et al., 2011; Muhling et al., 2007; Sabarros et al., 2009; Seki et al., 2002; Tew Kai and Marsac, 2010). On the one hand few individuals in our study had their $\delta^{15} \mathrm{~N}$ values directly impacted by mesoscale features which on the other hand did not influence the carbon signatures of the sampled organisms. Six specimens of the nomeid $C$. pauciradiatus and one $O$. volatilis (Ommastrephidae) were grouped by the regression tree based on their $\delta^{15} \mathrm{~N}$ values (Cyclonic 2, Fig. 4). These specimens were collected in the same cyclone sampled in November 2009 during the MC09B cruise, and had distinctly higher $\delta^{15} \mathrm{~N}$ signatures than their congeners sampled in other mesoscale features. Surprisingly, specimens from other species or taxa (leptocephali larvae, the squid Cranchia scabra, the crustacean Funchalia spp., and the fishes Argyropelecus aculeatus, Hygophum hygomii and Vinciguerria nimbaria) collected in the same cyclone did not show a similar pattern. Their $\delta^{15} \mathrm{~N}$ signatures did not differ significantly from specimens collected in other features (all KW test had a $p$-value much greater than $10 \%$ ). This singular pattern could suggest possible residency for the nomeid C. pauciradiatus into the eddy, while other species or taxa could move among the water masses. Lamkin (1997) showed indeed that adult spawning grounds and larval habitat of $C$. pauciradiatus can be tied to frontal systems along eddy rings in the Gulf of Mexico. Mesoscale features impacted the nitrogen signatures of Thunnus spp. only, with higher $\delta^{15} \mathrm{~N}$ signatures within anticyclones (KW test, $H=15.0, P<$ 0.001). Two extra individuals sampled in the same cyclone could have been added to the Cyclonic 2 group: one Decapterus sp. which had the highest $\delta^{15} \mathrm{~N}$ value (16.6\%) and one Lobianchia gemellarii $\left(\delta^{15} \mathrm{~N}=12.4 \%\right.$ ). In cyclonic eddies, vertical fluxes of nitrate can 
321 dominate production leading to higher $\delta^{15} \mathrm{~N}$ signatures of the phytoplankton compared with an anticyclonic eddy, where nitrate supply to the surface could be physically limited (Bakun, 2006; McGillicuddy Jr and Robinson, 1997; Muhling et al., 2007; Waite et al., 2007). To impact the isotopic signature of pelagic consumers such as micronekton organisms, one should assume that this isotopic baseline is incorporated and conserved through several trophic levels trapped in the water mass of the cyclonic eddy. However this hypothesis is challenged by the ecology and behaviour of micronekton organisms.

The vast majority of micronekton organisms typically occurs in the surface layer during the night and migrates below 400m depth during the day (Behagle et al., this issue). Micronekton ascents and descents during the crepuscular periods (dawn and dusk) characterize this process of diel vertical migration (Benoit-Bird et al., 2009). In the Humboldt Current system, the vertical extent of the water mass trapped in eddies has been recently estimated to $240 \mathrm{~m}$ and $530 \mathrm{~m}$ in cyclonic and anticyclonic eddies respectively, with a global decrease of the physical gradients with depth (Chaigneau et al., 2011). These estimates are most likely variable from eddy to eddy and from one area to another. In eddies of the Mozambique Channel, swirl velocities are weaker in deeper layers than they are at the surface (Ternon et al., this issue). In addition, Kolasinski et al. (2012) showed that physicochemical characteristics of deep waters (including carbon and nitrogen isotopic values of POM) from cyclonic and anti-cyclonic eddy of the Mozambique Channel were alike. Consequently, the diel vertical migration causes micronekton to stay half of the time in water masses weakly impacted by eddies. Contrary to the study of Godø et al. (2012) in the Norwegian Sea, we believe that horizontal structure is not preserved during diel vertical migration in the Mozambique Channel: migration did not take place in accordance with the 
water mass trapped in eddies. In addition, eddies are translated rather slowly in the

Mozambique Channel $\left(5.2 \mathrm{~cm} \cdot \mathrm{s}^{-1}\right.$; (de Ruijter et al., 2002) while the average speed of a mesopelagic fish was measured acoustically to be about $30 \mathrm{~cm} \cdot \mathrm{s}^{-1}$ (Torgersen and Kaartvedt,

2001). Therefore, fish and most likely squids would still have the ability to swim across eddies at any depth. However very few studies investigated how crustaceans swim. Morris et al. (1985) analyzed the swimming in a small calanoid copepod (Pleuromamma xiphias, $6 \mathrm{~mm}$ ): they estimated maximal velocities to be $0.3 \mathrm{~m} \cdot \mathrm{s}^{-1}$ during the power strokes of an entire swimming cycle, and less than $0.1 \mathrm{~m} . \mathrm{s}^{-1}$ during the recovery strokes. The total lengths of the three crustacean taxa in our study are at least five times the size of P. xiphias and maximal swimming velocity scales with body length. We thus believe that micronekton is rarely trapped in the water mass of a particular eddy and thus does not necessarily feed on concentrations of zooplankton prey found in the eddy only.

Isotopic incorporation in animal tissues is linked to turnover rates that vary according to tissue, body size, growth or taxon (Martínez del Rio et al., 2009). The dynamics of isotopic incorporation can then blur the interpretation of our field isotopic measurements. Indeed, a sampled micronekton specimen that had recently moved into an eddy from surrounding waters may have had a previous $\delta^{15} \mathrm{~N}$ or $\delta^{13} \mathrm{C}$ signature that would have been gradually modified as they fed on new food sources trapped in the eddy. Depending on tissue-specific isotopic turnover, stable isotope measurements reflect average dietary records over days (e.g, whole fish larvae; Herzka and Holt, 2000) to years (e.g., elasmobranch muscle; MacNeil et al., 2006; Logan and Lutcavage, 2010). No clear studies estimated isotopic turnovers for micronekton but several weeks seem a reasonable order of magnitude. Consequently, the 
particular isotope baseline of an eddy is likely not conserved through these pelagic consumers.

However, migration can be a multifaceted and plastic response of micronekton. Partial diel

372 vertical migration has been reported in the literature, showing that resident and migrant 373 strategies can co-exist in some populations (Mehner and Kasprzak, 2011; Olsson et al., 2006). In addition several taxa in our data were clearly epipelagic (leptocephali larvae, Salpa maxima, Thunnus sp., Decapterus sp.). Notwithstanding their swimming abilities and assuming a passive transport, all these species would then be more sensitive to eddy structure. If trapped in the water mass of the eddy, they can prey on local concentrations of zooplankton propagating the baseline of the "eddy" isotopic signature. This scenario might be true for the specimens of the grouping Cyclonic 2.

\subsection{Carbon isotope patterns}

382 There was no significant difference in $\delta^{13} \mathrm{C}$ signatures of micronekton between mesoscale features. The $\delta^{13} \mathrm{C}$ values ranged from -20.6 to $-17.3 \%$ suggesting that micronekton organisms sampled exploit different sources of primary production, giving rise to different trophic pathways. However, most of $\delta^{13} \mathrm{C}$ mean values encompassed a narrow range between -19 and $-18 \%$ (all squids, 19 fish taxa, two crustacean genera, Fig. 4b). Only gelatinous organisms and three fishes (Psenes spp., Diaphus metopoclampus and Pterycombus petersii) were depleted in ${ }^{13} \mathrm{C}$ compared with the other taxa. Leptocephali

389 larvae which could feed on detritical materials and fecal pellets (Lecomte-Finiger et al., 2004)

390 had the most ${ }^{13} \mathrm{C}$-depleted carbon signature with a large variance of $\delta^{13} \mathrm{C}$ values too. 391 Surprisingly, our $\delta^{13} \mathrm{C}$ values were intermediate between standard offshore pelagic 
signatures and nearshore signatures measured in this region (Hill et al., 2006; Kolasinski et al., 2012), suggesting that pelagic production in the Mozambique Channel could be partly supported by the transport and export of inorganic and organic particles from the Mozambican coast toward offshore area, through the "vacuum-cleaner effect" due to rotational dynamics of eddies (Tew-Kai and Marsac, 2009).

\subsection{Trophic levels of micronekton}

Micronekton form a key trophic link between top predators and zooplankton (Brodeur and Yamamura, 2005), and are theoretically assumed to constitute the tertiary level of pelagic food webs. The lowest trophic level except salps was occupied by leptocephali larvae ( $T L=$ 2.2), and TLs less than 3.0 were estimated for the carnivorous heteropod Carinaria lamarckii, the penaeids Funchalia spp. and juveniles of three fish taxa (Thunnus spp., Pterycombus petersii and Psenes spp.). The remaining estimated TLs encompassed a continuum of values between 3.1 and 4.2, very close to those obtained by Cherel et al. (2010) and Stowasser et al. (2012) for myctophids in the Southern Ocean. Our results show that micronekton sampled can occupy relatively high trophic positions: the high TL of the myctophid Diaphus metopoclampus probably fits with a diet based on euphausiids or small fish larvae, and the high TL of the crustacean Oplophorus typus is explained by a diet strongly dominated by detritus (Karuppasamy and Menon, 2004), which are known to be ${ }^{15} \mathrm{~N}$-enriched. However our organisms were preying upon a similar range of herbivorous and omnivorous consumers, mainly meso- or macrozooplankton.

Body size is known to play a crucial role in predator-prey interactions (Sheldon et al., 1977). Body length can influence $\delta^{15} \mathrm{~N}$ values (then TL) of one species because larger specimens can 
catch larger prey as they grow (e.g. Parry, 2008). However intraspecific variation in $\delta^{15} \mathrm{~N}$ with body length was identified in three fish taxa and one squid species only (Fig. 6 and Table 2).

For these taxa, the positive significant relationships may be indicative of larger specimens feeding at higher trophic levels. We probably cannot conclude for the other taxa as pelagic trawls used for sampling micronekton selected limited size ranges for each species (Table 1). Interestingly, a model with two intercepts and one slope was fitted to the data of the fish Cubiceps pauciradiatus. The common slope may be indicative of consistent ontogenetic variability (i.e. a similar intraspecific variation), while different intercepts can result from a shift in habitat use (i.e., $\delta^{15} \mathrm{~N}$ values impacted by a baseline change in a cyclonic eddy). Furthermore the linear relationship between $\mathrm{TL}$ and body length means of taxa was not significant $\left(F_{1,28}=1.95, P=0.17\right.$ for 30 taxa), showing that the structuring effect of size was not depicted in our data with regard to the range of the body length averages (Table 1). Leptocephali larvae were indeed an outlier in the dataset (very low TL associated with high body length) and salps were unfortunately not measured onboard.

But the interpretation of trophic level estimated from $\delta^{15} \mathrm{~N}$ values presents caveats. Isotopic baseline can vary from year to year and can be conserved through several trophic levels. Three salp samples were collected in December 2008 (MC08A) and one in November 2009 (MC09B) only, preventing statistical comparison. However $\delta^{15} \mathrm{~N}$ values were very close and year effect (a confounding variable with the cruise factor which was one covariate in the regression tree) was never significant. In addition sources of variation of the discrimination factor are numerous (Martinez del Rio et al., 2009). These biases in isotopic TL calculation can alter our estimates. In addition, the basic biology and ecology of micronekton 
439 (ontogenetic migration, feeding habits) remain poorly known, making interpretation 440 difficult.

\subsection{Limitations of the data}

443 The spatial and temporal resolutions of our isotope data are limited by the sampling coverage of the pelagic trawls that were carried out during two cruises. The two surveys did not sample the same patterns of mesoscale eddies. In 2009 (MC09B), mesoscale features were very stable and well established compared to 2008 (MC08A), where eddies were in their early phases (Ternon et al., this issue). Contrary to Waite et al. (2007) who investigated extensively the same dipole in one area, we sampled mesoscale features at different maturation phases. Eddies are characterized by their dimension, intensity (e.g., sea surface height, geostrophic and rotational velocities), lifetime, origin, trajectory, and propagation distance (Bakun, 2006; Chelton et al., 2011). In addition eddies develop over time scales of weeks to months while biological responses such as diel vertical migration can occur within a day. All these eddy properties and development phases shape biological responses and then impact the stable isotope signatures of the organisms.

In summary, biogeochemical and biological responses to mesoscale dynamics along the food chain up to mid-trophic levels such as micronekton are variable and the underlying mechanisms are complex to disentangle. The stable isotope method, based on timeintegrated assimilated food, allowed us to better depict the trophic relationships in this micronekton assemblage. Some species had distinct isotopic niches, but others showed 461 strong overlap. In addition isotopic differences attributed to mesoscale dynamics were evidenced for individuals of the same species. Thus the variations in stable isotope values in 
our data reflect a complex set of embedded processes linked to physical mesoscale dynamics

464

465

466

467

468

469

470

471

472

474

475

476

477

478

479

480

481

482

483

484

485

486

487

488

489

490

491

492

493

494

495

and basic biology and ecology of micronektonic organisms (e.g. vertical habitat, migration pattern, dietary habits and body length).

\section{ACKNOWLEDGEMENTS}

This work was mainly supported by the MESOBIO project which was funded by WIOMSA

(MASMA grant 2009-2011). IRD (France), Department of Environment Affairs (South Africa),

ASCLME, and SWIOFP also participated to the funding of surveys or research works. HDB was

granted by IRD, the French SCAC in Madagascar and the WIOMSA (MARGII). The authors

thank Dominique Dagorne, Hervé Demarcq and Jean-François Ternon for their help in this

work. We also thank John Logan and an anonymous reviewer who helped strengthen this

manuscript.

\section{REFERENCES}

Bailleul, F., Cott, C., Guinet, C., 2010. Mesoscale eddies as foraging area of a deep-diving predator, the southern elephant seal. Mar. Ecol. Prog. Ser. 408, 251-264.

Bakun, A., 2006. Fronts and eddies as key structures in the habitat of marine fish larvae: opportunity, adaptative response and competitive advantage. Sci. Mar. 70S2, 105-122.

Behagle, N., du Buisson, L., Josse, E., Lebourges-Dhaussy, A., Roudeau, G., Ménard, F. (2013). Mesoscale features and micronekton in the Mozambique Channel: an acoustic approach. Deep Sea Res. Part II

Benitez-Nelson, C.R., Bidigare, R.R., Dickey, T.D., Landry, M.R., Leonard, C.L., Brown, S.L., Nencioli, F., Rii, Y.M., Maiti, K., Becker, J.W., Bibby, T.S., Black, W., Cai, W.-J., Carlson, C.A., Chen, F., Kuwahara, V.S., Mahaffey, C., McAndrew, P.M., Quay, P.D., Rappe, M.S., Selph, K.E., Simmons, M.P., Yang, E.J., 2007. Mesoscale Eddies Drive Increased Silica Export in the Subtropical Pacific Ocean. Science 316, 1017-1021.

Benoit-Bird, K.J., Au, W.W.L., Wisdom, D.W., 2009. Nocturnal light and lunar cycle effects on diel migration of micronekton. Limnol. Ocean. 54, 1789-1800.

Bodin, N., Budzinski, H., Le Ménach, K., Tapie, N., 2009. ASE extraction method for simultaneous carbon and nitrogen stable isotope analysis in soft tissues of aquatic organisms. Anal. Chim. Acta 643, 54-60.

Brodeur, R.D., Yamamura, O., 2005. Micronekton of the North Pacific. PICES Sci Rep. No. 30, North Pacific Marine Science Organization, Sidney, BC. 
Chaigneau, A., Texier, M.L., Eldin, G., Grados, C., Pizarro, O., 2011. Vertical structure of mesoscale eddies in the eastern South Pacific Ocean: A composite analysis from altimetry and Argo profiling floats. J. Geophys. Res. 116, 16 PP.

Chelton, D.B., Schlax, M.G., Samelson, R.M., 2011. Global observations of nonlinear mesoscale eddies. Prog. Ocean. 91, 167-216.

Chelton, D.B., Schlax, M.G., Samelson, R.M., Szoeke, R.A. de, 2007. Global observations of large oceanic eddies. Geophys. Res. Lett. 34, 5 PP.

Cherel, Y., Ducatez, S., Fontaine, C., Richard, P., Guinet, C., 2008. Stable isotopes reveal the trophic position and mesopelagic fish diet of female southern elephant seals breeding on the Kerguelen Islands. Mar. Ecol. Prog. Ser. 370, 239-247.

Cherel, Y., Fontaine, C., Richard, P., Labat, J.-P., 2010. Isotopic niches and trophic levels of myctophid fishes and their predators in the Southern Ocean. Limnol. Ocean. 55, 324-332.

De Ruijter, W.P.M., Ridderinkhof, H., Lutjeharms J.R.E., Schouten, M.W., Veth, C., 2002. Observations of the flow in the Mozambique Channel. Geophys. Res. Lett. 29, 1502.

Domokos, R., 2009. Environmental effects on forage and longline fishery performance for albacore (Thunnus alalunga) in the American Samoa Exclusive Economic Zone. Fish. Ocean. 18, 419438.

Domokos, R., Seki, M.P., Polovina, J.J., Hawn, D.R., 2007. Oceanographic investigation of the American Samoa albacore (Thunnus alalunga) habitat and longline fishing grounds. Fish. Ocean. 16, 555-572.

Drazen, J.C., De Forest, L.G., Domokos, R., 2011. Micronekton abundance and biomass in Hawaiian waters as influenced by seamounts, eddies, and the moon. Deep Sea Res. Part I 58, 557-566.

Fanelli, E., Cartes, J.E., Papiol, V., 2011. Food web structure of deep-sea macrozooplankton and micronekton off the Catalan slope: Insight from stable isotopes. J. Mar. Syst. 87, 79-89.

Fry, B., 2006. Stable isotope ecology. Springer, New York.

God $\varnothing$, O.R., Samuelsen, A., Macaulay, G.J., Patel, R., Hjøllo, S.S., Horne, J., Kaartvedt, S., Johannessen, J.A., 2012. Mesoscale Eddies Are Oases for Higher Trophic Marine Life. Plos One 7, e30161.

Herzka, S.Z., Holt, G.J., 2000. Changes in isotopic composition of red drum (Sciaenops ocellatus) larvae in response to dietary shifts: potential applications to settlement studies. Can. J. Fish. Aquat. Sci. 57, 137-147.

Hill, J.M., McQuaid, C.D., Kaehler, S., 2006. Biogeographic and nearshore-offshore trends in isotope ratios of intertidal mussels and their food sources around the coast of southern Africa. Mar. Ecol. Prog. Ser. 318, 63-73.

Hyrenbach, K.D., Veit, R.R., Weimerskirch, H., Hunt Jr., G.L., 2006. Seabird associations with mesoscale eddies: the subtropical Indian Ocean. Mar. Ecol. Prog. Ser. 324, 271-279.

Karuppasamy, P.K., Menon, N.G., 2004. Food and feeding habits of the pelagic shrimp, Oplophorus typus from the deep scattering layer along the west coast of India. Indian J. Fish. 51, 17-24.

Kolasinski, J., Kaehler, S., Jaquemet, S., 2012. Distribution and sources of particulate organic matter in a mesoscale eddy dipole in the Mozambique Channel (south-western Indian Ocean): Insight from C and N stable isotopes. J. Mar. Syst. 96-97, 122-131.

Lambardi, P., Lutjeharms, J.R.E., Mencacci, R., Hays, G.C., Luschi, P., 2008. Influence of ocean currents on long-distance movement of leatherback sea turtles in the Southwest Indian Ocean. Mar. Ecol. Prog. Ser. 353, 289-301.

Lamkin, J. 1996. The Loop Current and the abundance of larval Cubiceps pauciradiatus (Pisces: Nomeidae) in the Gulf of Mexico: evidence for physical and biological interaction. Fish. Bull. 95, 250-266.

Lamont, T., Barlow, R., Morris, T., Van den Berg, M. (2013). Characterisation of mesoscale features and phytoplankton variability in the Mozambique Channel. Deep Sea Res. Part II

Lecomte-Finiger, R., Maunier, C., Khafif, M., 2004. Les larves de leptocéphales, ces méconnues. Cybium 28, 83-95.

Logan, J.M., Lutcavage, M.E., 2010. Stable isotope dynamics in elasmobranch fishes. Hydrobiologia 644, 231-244. 
MacNeil, M.A., Drouillard, K.G., Fisk, A.T., 2006. Variable uptake and elimination of stable nitrogen isotopes between tissues in fish. Can. J. Fish. Aquat. Sci. 63:345-353

Martínez del Rio, C., Wolf, N., Carleton, S.A., Gannes, L.Z., 2009. Isotopic ecology ten years after a call for more laboratory experiments. Biol. Rev. 84, 91-111.

McGillicuddy Jr, D.J., Robinson, A.R., 1997. Eddy-induced nutrient supply and new production in the Sargasso Sea. Deep Sea Res. Part I 44, 1427-1450.

McGillicuddy Jr, D.J., Robinson, A.R., Siegel, D.A., Jannasch, H.W., Johnson, R., T. D. Dickey, J. McNeil, A. F. Michaels, A. H. Knap, 1998. Influence of mesoscale eddies on new production in the Sargasso Sea. Nature 394, 263-266.

Mehner, T., Kasprzak, P., 2011. Partial diel vertical migrations in pelagic fish. J. Anim. Ecol. 80, 761770.

Ménard, F., Lorrain, A., Potier, M., Marsac, F., 2007. Isotopic evidence of distinct feeding ecologies and movement patterns in two migratory predators (yellowfin tuna and swordfish) of the western Indian Ocean. Mar. Biol. 153, 141-152.

Mizobata, K., Saitoh, S.I., Shiomoto, A., Miyamura, T., Shiga, N., Imai, K., Toratani, M., Kajiwara, Y., Sasaoka, K., 2002. Bering Sea cyclonic and anticyclonic eddies observed during summer 2000 and 2001. Prog. Ocean. 55, 65-75.

Morris, M.J., Gust, G., Torres, J.J., 1985. Propulsion efficiency and cost of transport for copepods: a hydromechanical model of crustacean swimming. Mar. Biol. 86, 283-295.

Muhling, B.A., Beckley, L.E., Olivar, M.P., 2007. Ichthyoplankton assemblage structure in two mesoscale Leeuwin Current eddies, eastern Indian Ocean: The Leeuwin Current and its Eddies. Deep Sea Res. Part II 54, 1113-1128.

Nel, D.C., Lutjeharms J.R.E., Pakhomov, E.A., Ansorge, I.J., Ryan, P.G., Klages, N.T.W., 2001. Exploitation of mesoscale oceanographic features by grey-headed albatross Thlassarche chrysostoma in the southern Indian Ocean. Mar. Ecol. Prog. Ser. 217, 15-26.

Olson, R.J., Popp, B.N., Graham, B.S., López-Ibarra, G.A., Galván-Magaña, F., Lennert-Cody, C.E., Bocanegra-Castillo, N., Wallsgrove, N.J., Gier, E., Alatorre-Ramírez, V., Ballance, L.T., Fry, B., 2010. Food-web inferences of stable isotope spatial patterns in copepods and yellowfin tuna in the pelagic eastern Pacific Ocean. Prog. Ocean. 86, 124-138.

Olsson, I.C., Greenberg, L.A., Bergman, E., Wysujack, K., 2006. Environmentally induced migration: the importance of food. Ecol. Lett. 9, 645-651.

Polovina, J.J., Balazs, G.H., Howell, E.A., Parker, D.M., Seki, M.P., Dutton, P.H., 2004. Forage and migration habitat of loggerhead (Caretta caretta) and olive ridley (Lepidochelys olivacea) sea turtles in the central North Pacific Ocean. Fish. Ocean. 13, 36-51.

Post, D.M., 2002. Using stable isotopes to estimate trophic position: models, methods, and assumptions. Ecology 83, 703-718.

Post, D.M., Layman, C.A., Arrington, D.A., Takimoto, G., Quattrochi, J., Montaña, C.G., 2007. Getting to the fat of the matter: models, methods and assumptions for dealing with lipids in stable isotope analyses. Oecologia 152, 179-189.

Potier, M., Marsac, F., Cherel, Y., Lucas, V., Sabatie, R., Maury, O., Ménard, F., 2007. Forage fauna in the diet of three large pelagic fishes (lancetfish, swordfish and yellowfin tuna) in the western equatorial Indian Ocean. Fish. Res. 83, 60-72.

Potier, M., Bach, P., Ménard, F., Marsac, F. (2013). Influence of mesoscale features on micronekton and top predators in the Mozambique Channel. Deep Sea Res. Part II

Quartly, G.D., Srokosz, M.A., 2004. Eddies in the southern Mozambique Channel. Deep Sea Res. Part II 51, 69-83.

Revill, A.T., Young, J.W., Lansdell, M., 2009. Stable isotopic evidence for trophic groupings and bioregionalization of predators and their prey in oceanic waters off eastern Australia. Mar. Biol. 156, 1241-1253.

Roberts, M., et al. (2013). Mechanics of dipole eddies in the western Mozambique Channel. Deep Sea Res.Part II 
Rubenstein, D.R., Hobson, K.A., 2004. From birds to butterflies: animal movement patterns and stable isotopes. Trends Ecol. Evol. 19, 256-263.

Sabarros, P.S., Ménard, F., Lévénez, J., TewKai, E., Ternon, J., 2009. Mesoscale eddies influence distribution and aggregation patterns of micronekton in the Mozambique Channel. Mar. Ecol. Prog. Ser. 395, 101-107.

Schouten, M.W., de Ruijter, W.P.M., van Leeuwen, P.J., Ridderinkhof, H., 2003. Eddies and variability in the Mozambique Channel. Deep-Sea Res. Part II 50, 1987-2003.

Seki, M.P., Polovina, J.J., Kobayashi, D.R., Bididgare R.R., Mitchum, G.T., 2002. An oceanographic characterization of swordfish (Xiphias gladius) longline fishing grounds in the springtime subtropical North Pacific. Fish. Ocean. 11, 251-266.

Sheldon, R.W., Sutcliffe, Jr., Paranjape, M.A., 1977. Structure of pelagic food chain and relationship between plankton and fish production. J. Fish. Res. Board Can. 34, 2344-2353.

Stowasser, G., Atkinson, A., McGill, R.A.R., Phillips, R.A., Collins, M.A., Pond, D.W., 2012. Food web dynamics in the Scotia Sea in summer: A stable isotope study. Deep Sea Res. Part II 59-60, 208-221.

Sweeting, C.J., Barry, J., Barnes, C., Polunin, N.V.C., Jennings, S., 2007. Effects of body size and environment on diet-tissue [delta]15N fractionation in fishes. J. Exp. Mar. Biol. Ecol. 340, 110.

Ternon, J.F., Barlow, R., Huggett, J., Kaehler, S., Marsac, F., Ménard, F., Potier, M., Roberts, M. (2013). An overview of recent field experiments on the ecosystem's mesoscale signature in the Mozambique Channel: from physics to upper trophic levels. Deep Sea Res. Part II

Tew Kai, E., Marsac, F., 2010. Influence of mesoscale eddies on spatial structuring of top predators' communities in the Mozambique Channel. Prog. Ocean. 86, 214-223.

Tew-Kai, E., Marsac, F., 2009. Patterns of variability of sea surface chlorophyll in the Mozambique Channel: A quantitative approach. J. Mar. Syst. 77, 77-88.

Torgersen, T., Kaartvedt, S., 2001. In situ swimming behaviour of individual mesopelagic fish studied by split-beam echo target tracking. Ices J. Mar. Sci. 58, 346-354.

Vanderklift, M.A., Ponsard, S., 2003. Sources of variation in consumer-diet ?15N enrichment: a metaanalysis. Oecologia 136, 169-182.

Venables, W.N., Ripley, B.D., 2002. Modern Applied Statistics with S, fourth ed., Springer, New York. Waite, A.M., Muhling, B.A., Holl, C.M., Beckley, L.E., Montoya, J.P., Strzelecki, J., Thompson, P.A., Pesant, S., 2007. Food web structure in two counter-rotating eddies based on [delta]15N and [delta]13C isotopic analyses: The Leeuwin Current and its Eddies. Deep Sea Res. Part II 54, 1055-1075.

Weimerskirch, H., Le Corre, M., Jaquemet, S., Potier, M., Marsac, F., 2004. Foraging strategy of a top predator in tropical waters: great frigatebirds in the Mozambique Channel. Mar. Ecol. Prog. Ser. 275, 297-308.

Young, J.W., Bradford, R., Lamb, T.D., Clementson, L.A., Kloser, R., Galea, H., 2001. Yellowfin tuna (Thunnus albacares) aggregations along the shelf break off south-eastern Australia: links between inshore and offshore processes. Mar. Freshw. Res. 52, 463-474. 
641 Table 1. Body lengths and ranges (standard length for fishes, dorsal mantle length for squids,

642 cephalothorax length for crustaceans, total length for gelatinous organisms; in $\mathrm{mm}), \delta^{13} \mathrm{C}$ 643 and $\delta^{15} \mathrm{~N}$ values (per mil), $\mathrm{C} / \mathrm{N}$ ratios, and estimated trophic levels of micronekton from the 644 Mozambique Channel. Species or taxa are placed in broad class. Total number $n$ and 645 numbers per Anticyclone, Cyclone, Divergence, Front, and Shelf are indicated. Values are 646 mean \pm standard deviation. * indicates taxon for which body length effect was tested.

647

648 Table 2. Linear regression models fitted to $\delta^{15} \mathrm{~N}$ values (per mil) and body length (SL: 649 standard length in $\mathrm{mm}$; DML: dorsal mantle length in $\mathrm{mm}$ ) of four taxa of micronekton from 650 the Mozambique Channel. Models fitted to the squid Ornithoteuthis volatilis, and for the fish 651 taxa Decapterus sp., Lestrolepis intermedia, Myctophum spinosum, Psenes spp. and 652 Symbolophorus evermanni were not significant. Sample sizes and body length ranges 653 precluded model fitting for the remaining taxa. 


\begin{tabular}{|c|c|c|c|c|c|c|c|c|c|c|c|c|c|c|}
\hline Broad class & Species & Phase & $\mathrm{n}$ & $\begin{array}{l}\text { Body length } \\
\text { mean }(\mathrm{mm})\end{array}$ & $\begin{array}{l}\text { Body length } \\
\text { range }(\mathrm{mm})\end{array}$ & $\delta^{13} \mathrm{C}$ & $\delta^{15} \mathrm{~N}$ & $\mathrm{C} / \mathrm{N}$ & $\mathrm{TL}$ & Anticyclone & Cyclone & Divergence & Front & Shelf \\
\hline \multirow{4}{*}{$\begin{array}{l}\text { Gelatinous } \\
\text { organisms }\end{array}$} & Carinaria lamarckii & adults & 5 & 33.0 & $30-40$ & $-19.7 \pm 0.28$ & $7.4 \pm 0.61$ & $3.4 \pm 0.19$ & $2.7 \pm 0.2$ & & 5 & & & \\
\hline & Leptocephali larvae & larvae & 10 & 217.6 & $170-260$ & $-20.6 \pm 0.57$ & $5.8 \pm 1.55$ & $4.2 \pm 0.37$ & $2.2 \pm 0.5$ & & 5 & & & 5 \\
\hline & Salpa maxima & solitary zooid & 5 & & - & $-19.4 \pm 0.38$ & $5.2 \pm 0.11$ & $4.1 \pm 0.21$ & 2 & & & & 1 & 4 \\
\hline & Siphonophora & & 5 & 42.3 & $40-45$ & $-19.3 \pm 0.47$ & $8.5 \pm 0.63$ & $3.2 \pm 0.11$ & $3.1 \pm 0.2$ & 3 & & & & 2 \\
\hline \multirow{3}{*}{ Squids } & Cranchia scabra & juveniles & 9 & 40.1 & $35-47.1$ & $-18.6 \pm 0.49$ & $9.4 \pm 0.44$ & $3.1 \pm 0.21$ & $3.3 \pm 0.1$ & 4 & 5 & & & \\
\hline & Ornithoteuthis volatilis* & juveniles \& adults & 18 & 102.3 & $63.8-179$ & $-18.5 \pm 0.4$ & $9.5 \pm 0.8$ & $3.1 \pm 0.07$ & $3.4 \pm 0.2$ & & 1 & 7 & 5 & 5 \\
\hline & Sthenoteuthis oualaniensis* & juveniles \& adults & 77 & 92.8 & $21.7-360$ & $-18.2 \pm 0.35$ & $9.4 \pm 0.77$ & $3.1 \pm 0.08$ & $3.3 \pm 0.2$ & 19 & & 38 & 14 & 6 \\
\hline \multirow{3}{*}{ Crustaceans } & Funchalia spp. & adults & 22 & 16.4 & $13.8-18.4$ & $-18.6 \pm 0.27$ & $7.8 \pm 0.8$ & $3 \pm 0.07$ & $2.8 \pm 0.3$ & & 8 & 3 & 7 & 4 \\
\hline & Oplophorus sp. & adults & 8 & 13.0 & $12.7-13.5$ & $-17.3 \pm 0.24$ & $9.3 \pm 0.94$ & $3 \pm 0.04$ & $3.3 \pm 0.3$ & & 3 & & 5 & \\
\hline & Oplophorus typus & adults & 10 & 13.0 & $11.6-14.4$ & $-18.1 \pm 0.38$ & $10.2 \pm 0.32$ & $3.3 \pm 0.15$ & $3.6 \pm 0.1$ & 5 & & 5 & & \\
\hline \multirow{22}{*}{ Fishes } & Argyropelecus aculeatus & adults & 23 & 56.8 & $42-77$ & $-18.5 \pm 0.46$ & $10.5 \pm 0.88$ & $3.1 \pm 0.08$ & $3.7 \pm 0.3$ & & 3 & 10 & 10 & \\
\hline & Bramidae* & juveniles & 6 & 82.2 & $43-152$ & $-18.9 \pm 0.61$ & $9.2 \pm 0.86$ & $3.1 \pm 0.03$ & $3.3 \pm 0.3$ & & 2 & 3 & 1 & \\
\hline & Bregmaceros macclellandii & adults & 5 & 77.6 & $71-82$ & $-18.6 \pm 0.15$ & $10.9 \pm 0.44$ & $3.1 \pm 0.02$ & $3.8 \pm 0.1$ & & & & 5 & \\
\hline & Ceratoscopelus warmingii & adults & 5 & 59.6 & $53-65$ & $-18.9 \pm 0.26$ & $9.4 \pm 0.57$ & $3.1 \pm 0.02$ & $3.3 \pm 0.2$ & 5 & & & & \\
\hline & Cubiceps pauciradiatus* & juveniles \& adults & 55 & 98.1 & $23-140$ & $-18.2 \pm 0.4$ & $9 \pm 2.23$ & $3.1 \pm 0.06$ & $3.2 \pm 0.7$ & & 6 & 37 & 7 & 5 \\
\hline & Decapterus sp.* & juveniles & 13 & 83.1 & $35-116$ & $-18.5 \pm 0.23$ & $9.2 \pm 2.23$ & $3.1 \pm 0.07$ & $3.3 \pm 0.7$ & & 10 & & 3 & \\
\hline & Diaphus garmani & adults & 5 & 56.2 & $40-75$ & $-18.4 \pm 0.35$ & $10.4 \pm 0.94$ & $3.3 \pm 0.03$ & $3.7 \pm 0.3$ & & & & 5 & \\
\hline & Diaphus metopoclampus & adults & 6 & 57.7 & $54-62$ & $-19.3 \pm 0.19$ & $12.1 \pm 0.44$ & $3.3 \pm 0.04$ & $4.2 \pm 0.1$ & & & 5 & 1 & \\
\hline & Diaphus richardsoni & adults & 39 & 47.0 & $36-59$ & $-18.9 \pm 0.23$ & $10.8 \pm 0.52$ & $3.2 \pm 0.1$ & $3.8 \pm 0.2$ & 5 & & & 14 & 20 \\
\hline & Diaphus spp. & adults & 16 & 62.7 & $50-80$ & $-18.5 \pm 0.29$ & $10.5 \pm 0.62$ & $3.1 \pm 0.04$ & $3.7 \pm 0.2$ & 5 & & & 5 & 6 \\
\hline & Gonostoma elongatum & juveniles \& adults & 5 & 108.8 & $96-120$ & $-18.9 \pm 0.12$ & $9.7 \pm 0.39$ & $3 \pm 0.02$ & $3.4 \pm 0.1$ & & & 5 & & \\
\hline & Gymnoscopelus sp. & adults & 5 & 68.6 & $60-76$ & $-18.6 \pm 0.19$ & $10.2 \pm 0.38$ & $3.1 \pm 0.02$ & $3.6 \pm 0.1$ & & & & 5 & \\
\hline & Hygophum hygomii & adults & 15 & 52.1 & $37.3-62$ & $-18.8 \pm 0.2$ & $9.9 \pm 0.66$ & $3.1 \pm 0.02$ & $3.5 \pm 0.2$ & 5 & 5 & 1 & 4 & \\
\hline & Lestrolepis intermedia* & juveniles \& adults & 17 & 127.1 & $75-171$ & $-18.8 \pm 0.48$ & $9.7 \pm 0.83$ & $3.2 \pm 0.09$ & $3.4 \pm 0.3$ & & 2 & 4 & 3 & 8 \\
\hline & Lobianchia gemellarii & adults & 5 & 50.0 & $45-70$ & $-18.4 \pm 0.18$ & $11.1 \pm 0.73$ & $3.1 \pm 0.01$ & $3.9 \pm 0.2$ & & 1 & & & 4 \\
\hline & Myctophum spinosum* & juveniles \& adults & 33 & 65.7 & $40-86$ & $-18.8 \pm 0.24$ & $8.9 \pm 0.38$ & $3.2 \pm 0.05$ & $3.2 \pm 0.1$ & 2 & & 16 & 10 & 5 \\
\hline & Psenes spp.* & juveniles & 8 & 47.4 & $36-76$ & $-19.2 \pm 0.65$ & $7.6 \pm 0.34$ & $3.2 \pm 0.24$ & $2.8 \pm 0.1$ & 2 & 6 & & & \\
\hline & Pterycombus petersii & juveniles & 5 & 58.2 & $35-77$ & $-19.6 \pm 0.2$ & $8.2 \pm 0.66$ & $3 \pm 0.03$ & $2.9 \pm 0.2$ & & 3 & 2 & & \\
\hline & Scopelosaurus hoedti & adults & 6 & 123.7 & $112-126$ & $-18.9 \pm 0.04$ & $11.4 \pm 0.33$ & $3.1 \pm 0.01$ & $3.9 \pm 0.1$ & & 1 & & & 5 \\
\hline & Symbolophorus evermanni* & adults & 57 & 77.4 & $42-108$ & $-18.6 \pm 0.24$ & $9.3 \pm 0.69$ & $3.2 \pm 0.07$ & $3.3 \pm 0.2$ & 5 & & 30 & 12 & 10 \\
\hline & Thunnus spp.* & juveniles & 33 & 43.0 & $23-84$ & $-18.3 \pm 0.51$ & $7 \pm 0.8$ & $3.1 \pm 0.06$ & $2.6 \pm 0.2$ & 8 & 6 & 16 & & 3 \\
\hline & Vinciguerria nimbaria & adults & 14 & 39.9 & $32-46$ & $-18.8 \pm 0.29$ & $10 \pm 0.43$ & $3.1 \pm 0.03$ & $3.5 \pm 0.1$ & & 5 & 5 & 4 & \\
\hline
\end{tabular}


657 Table 2

\begin{tabular}{llccc}
\hline Taxon & Regression equation & $\mathrm{r}^{2}(\%)$ & $p$ & $n$ \\
\hline Bramidae & $\delta^{15} \mathrm{~N}=7.77+0.0179 \times \mathrm{SL}$ & 87.4 & 0.006 & 6 \\
Thunnus spp. & $\delta^{15} \mathrm{~N}=6.05+0.0226 \times \mathrm{SL}$ & 19.9 & 0.01 & 33 \\
Sthenoteuthis oualaniensis & $\delta^{15} \mathrm{~N}=8.27+0.0122 \times \mathrm{DML}$ & 46.4 & $<0.0001$ & 76 \\
Cubiceps pauciradiatus (not Cyclone) & $\delta^{15} \mathrm{~N}=6.04+0.0242 \times \mathrm{SL}$ & 90.24 & $<0.0001$ & 6 \\
Cubiceps pauciradiatus (Cyclone) & $\delta^{15} \mathrm{~N}=11.80+0.0242 \times \mathrm{SL}$ & & & 49 \\
\hline
\end{tabular}

659 
660

661

662

663

664

665

666

667

668

669

670

671

672

673

674

675

676

677

678

679

680

681

682

Fig. 1. Map showing the 34 sampling stations carried out in 2008 (cruise MC08) and 2009 (cruise MC09B) in the Mozambique Channel. Stations are categorized according to mesoscale features (no cyclone was sampled in MC08A).

Fig. 2. Summary of $\delta^{13} \mathrm{C}$ and $\delta^{15} \mathrm{~N}$ isotope signatures (mean \pm standard deviation in per mil) of micronekton taxa sampled in the Mozambique Channel. Set diagrams group the four broad categories (fishes, squids, crustaceans and gelatinous organisms).

Fig. 3. $\delta^{15} \mathrm{~N}(\mathrm{a})$ and $\delta^{13} \mathrm{C}(\mathrm{b})$ isotope signatures (mean \pm standard deviation in per mil) of micronekton taxa sampled in the Mozambique Channel. Taxa are placed in broad class and then isotope signatures of both nitrogen and carbon are sorted in order of decreasing depletion.

Fig. 4. Pruned regression tree that predicts the $\delta^{15} \mathrm{~N}$ signatures of five groups of micronekton organisms. Each terminal node is characterized by $\delta^{15} \mathrm{~N}$ value (per mil), number of individuals, corresponding taxa and mesoscale feature (A - Anticyclonic, C - Cyclonic, D Divergence, F - Frontal, S - Shelf). Covariates used to develop the tree are taxon and mesoscale features.

Fig. 5. Pruned regression tree that predicts the $\delta^{13} \mathrm{C}$ signatures of four groups of micronekton organisms. Each terminal node is characterized by $\delta^{13} \mathrm{C}$ value (per mil), number of individuals, corresponding taxa and mesoscale feature (A - Anticyclonic, C - Cyclonic, D Divergence, F - Frontal, S - Shelf). Covariate used to develop the tree is taxon. 
684 Fig. 6. $\delta^{15} \mathrm{~N}$ values (per mil) from (a) Bramidae (b) Sthenoteuthis oualaniensis (c) Cubiceps 685 pauciradiatus (d) Thunnus spp. plotted versus body length (standard length in $\mathrm{mm}$ for (a), (c) 686 and (d); dorsal mantle length in $\mathrm{mm}$ for (b)). Simple linear regressions for $\delta^{15} \mathrm{~N}$ values versus 687 body length are plotted (see text and Table 2). 


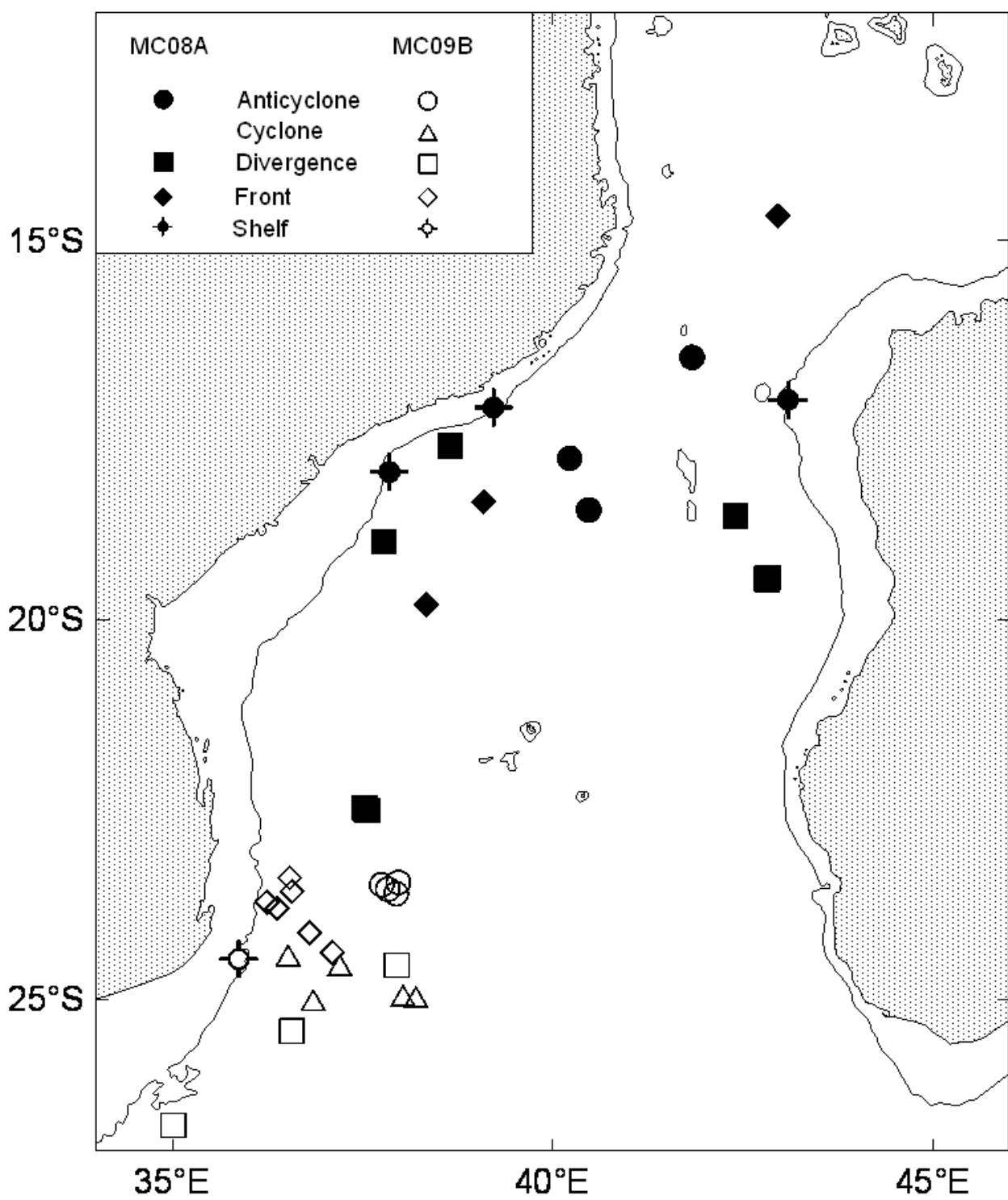

689

Fig.1 


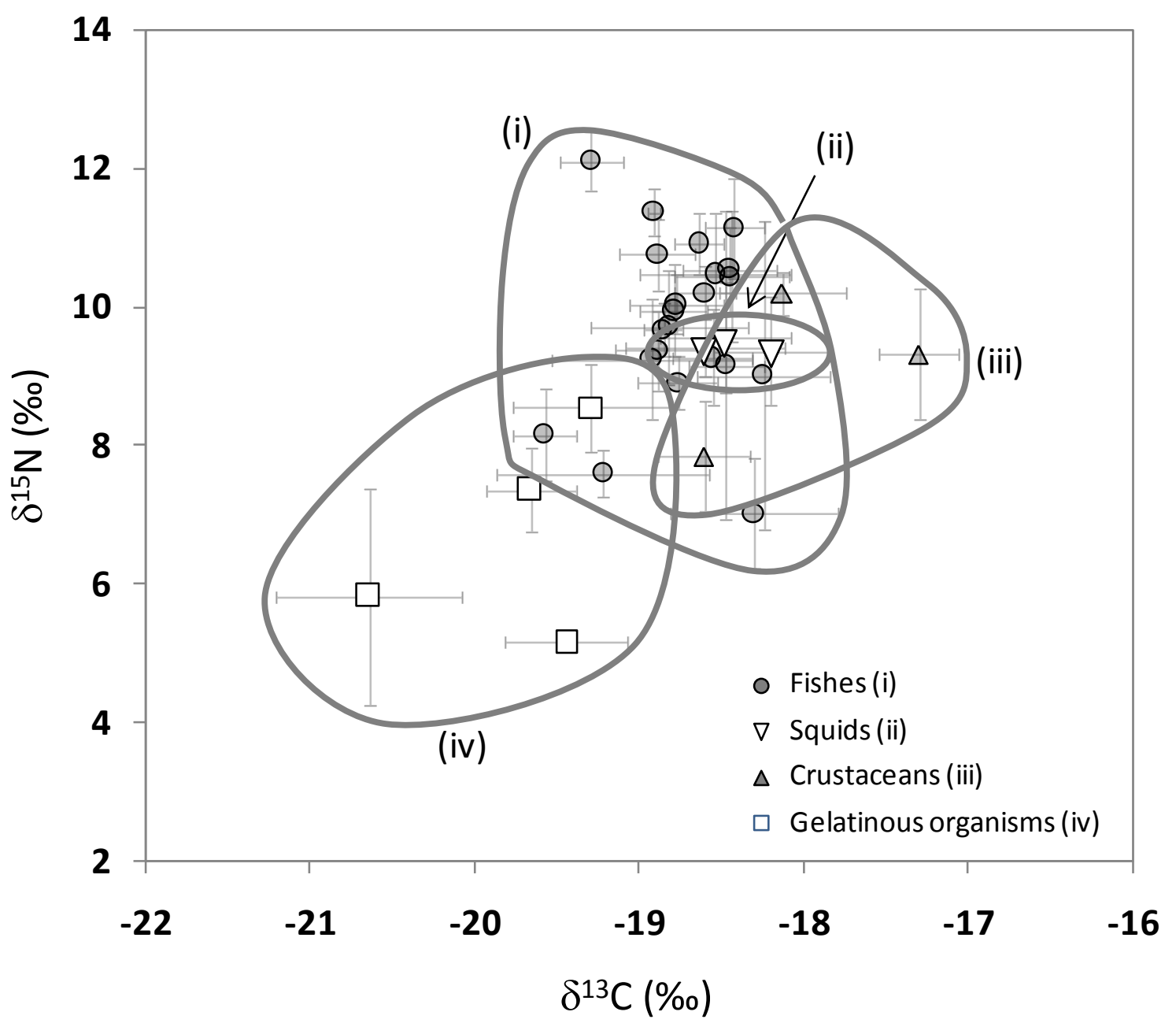

690

Fig. 2 
(a)

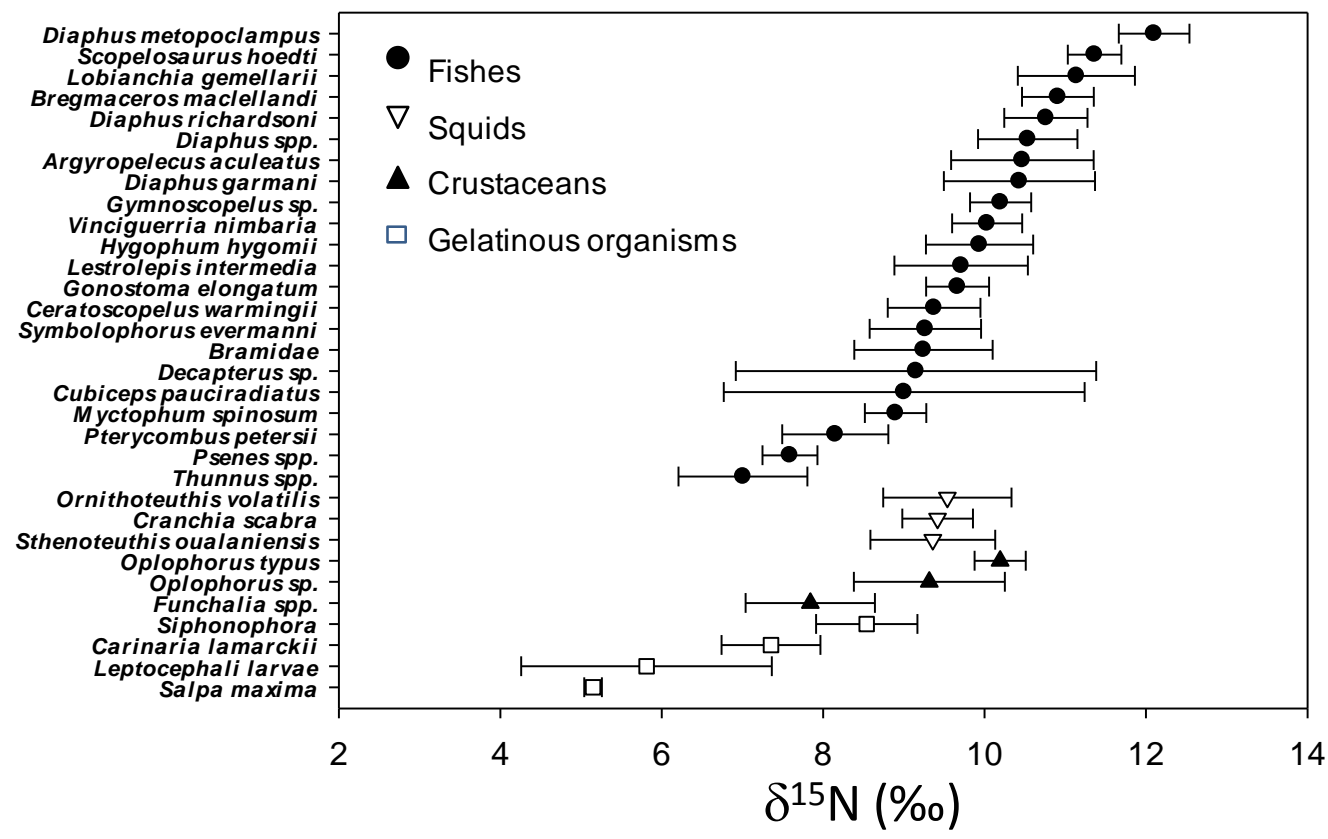

(b)

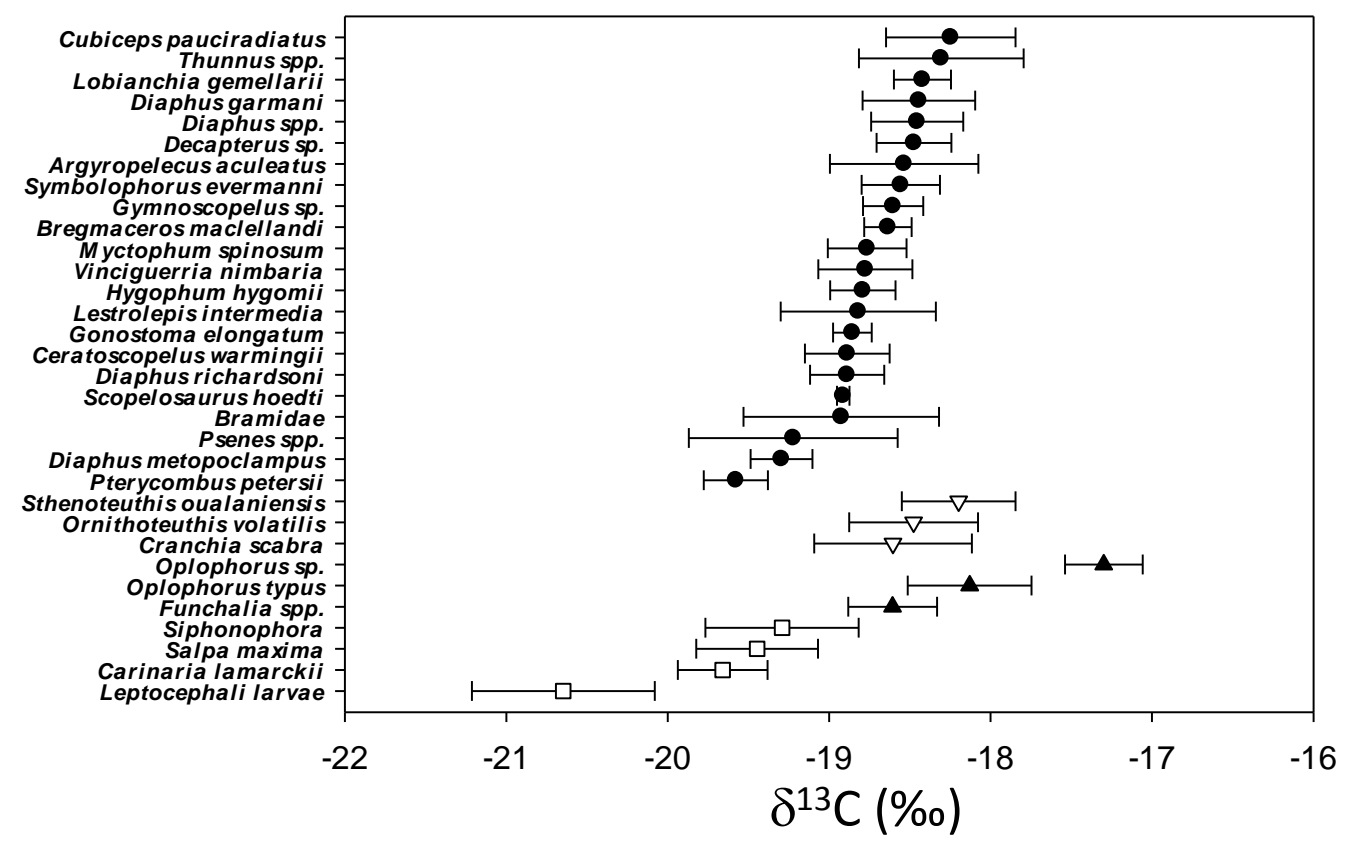




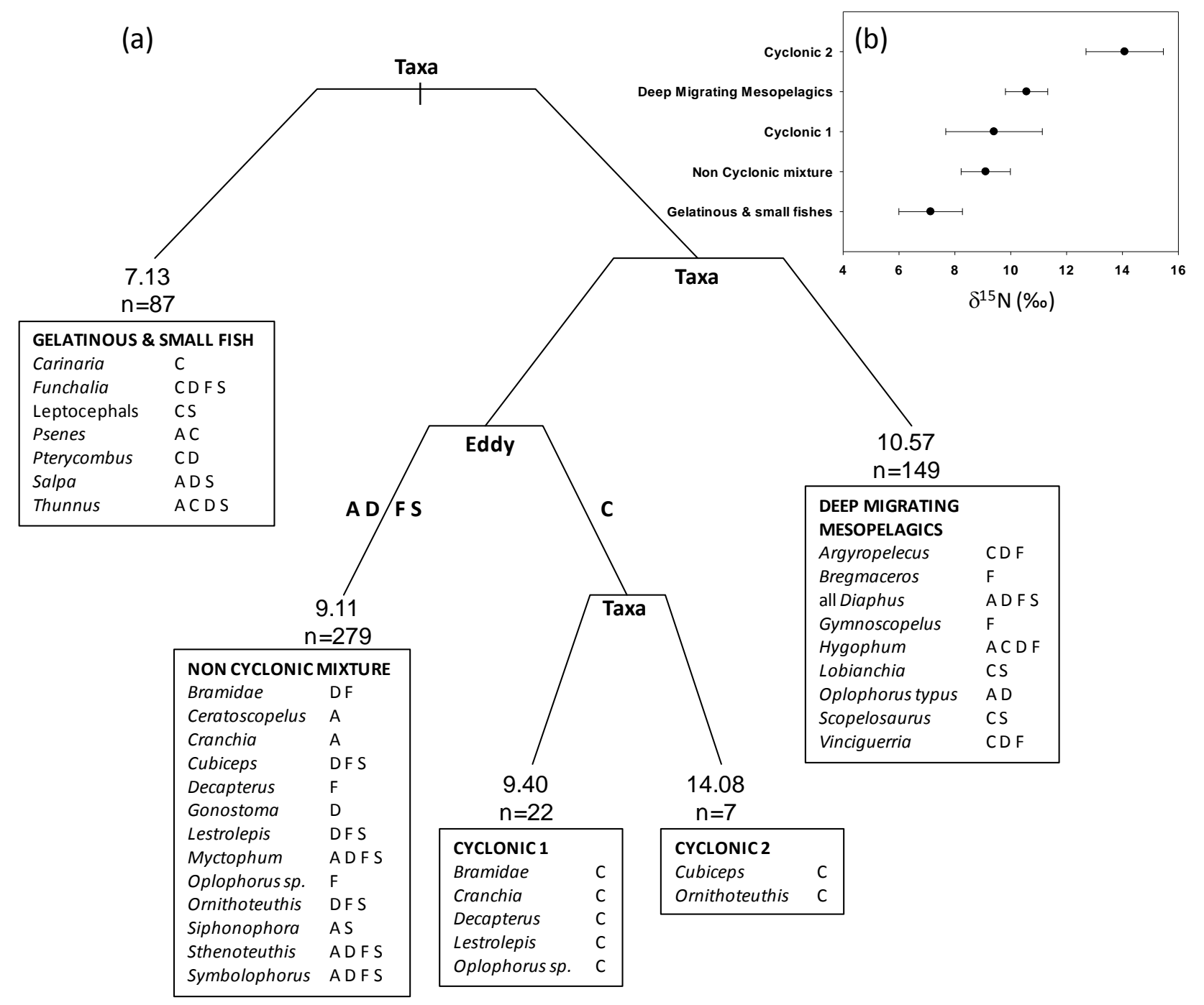






Fig. 5 

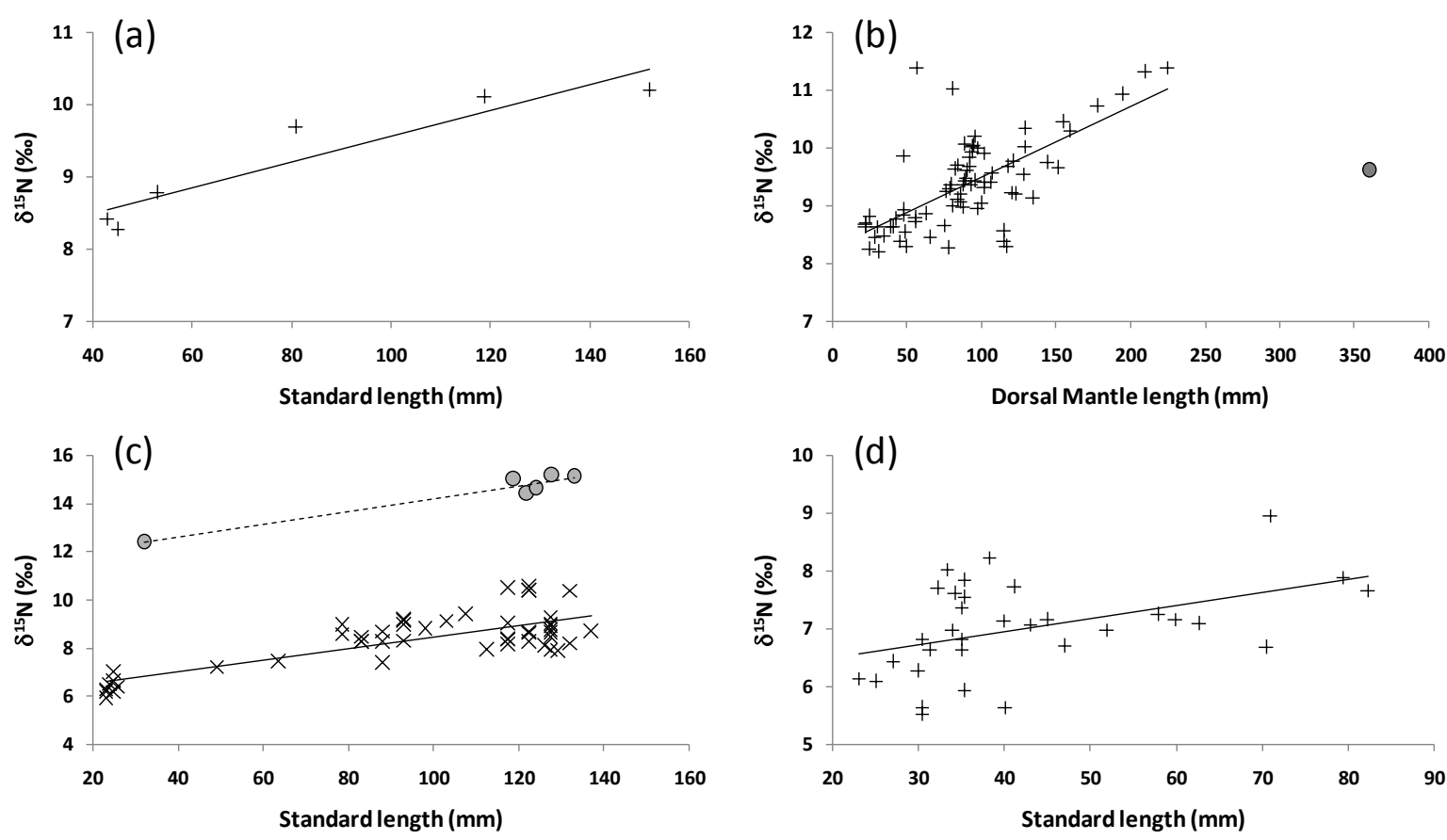

$699 \quad$ Fig.6 